"side hustle"). He has a strong commitment to his children's education. But I suspect that many other residents in this lowincome borough of the Bronx may share Miguel's values but are unable to realize their hopes. In that respect, Miguel is privileged-but surely not as privileged as those of us, like me, who are able to sequester at home and avoid placing ourselves at risk of illness and death.

\section{References}

1. Correal A, Jacobs A, Jones RC. Losses sweeping immigrant enclaves in Queens. NY Times. 2020 April 10[cited 2020 Apr 10]. Available from: at https://www.nydailynews.com/opinion/ny-letter-april-6-202004064nrn5c7udbfendrxms2luhvccy-story.html

2. NewYorkStateTaskForce on Life and the Law.NewYorkState Department of Health. Ventilator Allocation Guidelines. November 2015[cited 2020 Apr10]. Available at:https://www.health.ny.gov/regulations/task_force/ reports_publications/docs/ventilator_guidelines.pdf.

3. Ackerman, FN. The ethics of it. NY Daily News. 2020 April 6 [cited 2020 Apr 10]. Available from: https://www.nydailynews.com/opinion/nyletter-april-6-20200406-4nrn5c7udbfendrxms2luhvccy-story.html

4. Emanuel EJ, Persad G, Upshur R, Thome B, Parker M, Glickman A, et al .Fair allocation of scarce medical resources in the time of Covid-19. $N$ Engl J Med. 2020 Mar 23 [cited 2020 Apr 8]. doi: 10.1056/NEJMsb2005114. Available from: https://www.nejm.org/doi/10.1056/NEJMsb2005114

\title{
Death in the time of coronavirus
}

\section{GEORGE THOMAS}

\section{Abstract}

The lockdown of the country, imposed by the government of India, has resulted in additional suffering for the poor without any tangible benefit. The germ theory of disease is an important contribution to human welfare. However, disease has social determinants. Responses to infectious epidemics should be based on social conditions, not only from considerations of equity, but also because they are important for success. Advice from the World Health Organisation has to be tailored to the social realities in India. Current response by the government of India has confined the poor to ghettos. They have lost the means of livelihood without a proper social security net. It is not possible for them to practise social distancing or proper hygiene. The lockdown has the effect of making conditions worse for the poor.

Keywords: Covid-19 pandemic, resource allocation, social origins of disease, unplanned lockdown, diversion of resources. lack of social security

The response of the government of India to the potential threat from the new coronavirus, emphasised once again the deep fault lines in Indian society. On January 30, the World Health Organisation declared the virus a public health emergency of international concern. It was late March before the government decided to act.

In these two months it was business as usual in India. Riots took place in Delhi under the unwatchful eyes of the security apparatus. A mega political show was put on for the President of the United States of America who claimed that he had been promised that millions of people would greet him (1).

Author: George Thomas (george.s.thomas@gmail.com), Chief Orthopaedic Surgeon, St Isabel's Hospital, Mylapore, Chennai 600004 INDIA.

To cite: Thomas G. Death in the time of coronavirus. Indian J Med Ethics. 2020 Apr-Jun;5(2) NS: 98-9. DOI: 10.20529/JME.2020.036.

Published online on April 11, 2020.

(๑) Indian Journal of Medical Ethics 2020
These events underline the callousness with which a lockdown of the entire country was announced suddenly at $8 \mathrm{pm}$ on March 24. It boggles the imagination to believe that the Prime Minister and his advisors were unaware of the terrible consequences this decision would impose on the vast majority of the population. According to the World Bank, 659 million people or half the country's population are poor, and 176 million live in extreme poverty (2). No measures were announced to take care of them. It comes as no surprise that several lakhs of people, who migrate in search of work, crammed into every available means of transport to return to their homes. Thousands trekked long distances (3).

All this demonstrated, in the starkest terms imaginable, that social distancing was not for them. This was yet another luxury item that they could only gaze at.

\section{Models of disease}

The germ theory of disease was a remarkable intellectual contribution. It established that infections are due to microorganisms and laid the foundation for developing treatments aimed at targeting these micro-organisms. Long before the development of effective vaccines, antibiotics and anti-virals which are tools to treat the infected person, techniques of disinfection and quarantine were used to prevent the spread of disease. The great success of antibiotics and antivirals initially overshadowed the social origins of disease and its spread. The re-emergence of epidemics and pandemics in the modern world brought to the fore an insistent and persistent body of opinion that has maintained that disease has to be understood in a social context (4). Treatment of the individual patient is important, but it is no less important to understand the environmental and social conditions in which an individual becomes ill (5).

\section{Policy implications}

How the knowledge of the interplay between the social and the individual is used to determine policy emphasises the fault lines between nations and closer to home, within 
nations. The reports of the large numbers dying from the new coronavirus in some European nations is merely a quirk of fate. Infectious diseases usually affect the poor and malnourished far more than they affect the more privileged. The fact that more well-off people are likely to travel by air is an important reason why, in the modern world, new infections affect them early. Economic success and improved standards of living have translated into longer life expectancy, especially in the developed nations. Older people are more likely to die if they contract an infection.

\section{Response of the Government of India}

The response of the Indian government amounts to not merely abandoning the poor to their fate but imposing an additional burden on them. The hygiene and social distancing policies are simply impossible for them unless the government provides the resources which it shows no inclination to do. Containment has translated into sealing off the poor into densely packed ghettos. It is no secret that infrastructure and human resources for critical care in India are so miniscule, that we have no meaningful ability to respond should large numbers become seriously ill. It is well known that the virus spreads quickly. It is also well known that older people with pre-existing illnesses like hypertension and diabetes mellitus are more likely to die. Though all infections tend to affect the poor more than the well-off, the spread of the new coronavirus seems more equitable. It is clear that the measures the government has taken will protect the better-off while increasing the chances of infection among the poor. In addition, the diversion of all government medical care resources to the virus has cut off what little access the poor had to treatment for the everyday illnesses which affect them.

The economic consequences of the lockdown will be catastrophic for the poor. The loss of employment and livelihood will have an adverse effect for years to come. The strategy of allowing the virus to spread and waiting for herd immunity to reduce its ill effects is clearly the better option for them. Livelihoods will be protected and most of the young will survive.

\section{International response}

The advice of the World Health Organisation to "isolate, test, treat and trace", is possible only for the well-off nations. Should not this body which is supposed to advise governments everywhere have suggested alternate strategies based on the impressive data it has collected on the social determinants of health? Should it not have been aware that the test (reverse transcriptase polymerase chain reaction, RT-PCR) was expensive, required skilled human resources and was not easily available? Did it take a genius to know that the test and supplies like personal protective equipment would be cornered by the richer nations, leaving the poorer countries exposed and vulnerable? Is it too much to imagine that in the modern world we could have at least attempted a global response? Such a response has not been difficult in imposing economic blockade on nations. Global agreement is quickly sought for war both traditional and economic. Winning the peace still seems an arduous task for our leaders.

The possibility of death in the time of the coronavirus has laid bare the deep fault lines in society and the control of powerful old men on world policy. This disease has shown a tendency to kill more old men than any other demographic (6). Most politicians and policy makers are old. There is a clear conflict of interest. They have chosen the option which gives them the maximum chance of survival, while increasing the chances of long-term poverty and premature death for the young and the poor. The coronavirus causes the disease, but who lives and who dies are largely determined by the decisions the powerful make. Equity and ethics must guide these decisions.

\section{References}

1. Withnall A. Trump says Modi promised 'millions and millions' of people will greet him on first India trip. Independent. 2020 Feb 12 [cited 2020 Apr 8]. Available from: https://www.independent.co.uk/news/world/ asia/trump-india-visit-modi-delhi-motera-cricket-stadium-a9331511. html

2. World Bank. Poverty and equity brief:India.WB;2019 Oct[cited $2020 \mathrm{Apr}$ 8]. Available from: https://databank.worldbank.org/data/download/ poverty/33EF03BB-9722-4AE2-ABC7-AA2972D68AFE/Global_POVEQ_ IND.pdf

3. The Hindu Net Desk. Lockdown displaces lakhs of migrants. 2020 March 31 [cited 2020 Apr 8]. Available from: https://www.thehindu.com/ specials/lockdown-displaces-lakhs-of-migrants/article31214375.ece

4. Marmot M. Social determinants of health inequalities. Lancet. 2005 Mar 19-25; 365(9464):1099-104.

5. Weiss RA, McMichael AJ. Social and environmental risk factors in the emergence of infectious diseases. Nat Med. 2004 [cited 2020 Apr8]; 10(Suppl 12): S70-76. Available from: https://www.ncbi.nlm.nih.gov/ pmc/articles/PMC7095886/

6. Mooney C, Kaplan S, Kim MJ.The coronavirus is killing far more men than women. Washington Post. 2020 Mar 19[cited 2020 Apr 8] Available from: https://www.washingtonpost.com/climate-environment/2020/03/19/ coronavirus-kills-more-men-than-women/ 